\title{
Present and Future of Seaweed Cultivation and Its Applications in Colombia
}

\author{
Juan Pablo Arias-Echeverri ${ }^{1, *}$, Paula Andrea Zapata-Ramírez ${ }^{2}$, Margarita Ramírez-Carmona ${ }^{1}$, \\ Leidy Rendón-Castrillón ${ }^{1}$ and Carlos Ocampo-López ${ }^{1}$ (i)
}

check for

updates

Citation: Arias-Echeverri, J.P.; Zapata-Ramírez, P.A.; RamírezCarmona, M.; Rendón-Castrillón, L.; Ocampo-López, C. Present and Future of Seaweed Cultivation and Its Applications in Colombia. J. Mar. Sci. Eng. 2022, 10, 243. https:// doi.org/10.3390/jmse10020243

Academic Editor: Sang Heon Lee

Received: 7 January 2022

Accepted: 8 February 2022

Published: 11 February 2022

Publisher's Note: MDPI stays neutral with regard to jurisdictional claims in published maps and institutional affiliations.

Copyright: (C) 2022 by the authors. Licensee MDPI, Basel, Switzerland. This article is an open access article distributed under the terms and conditions of the Creative Commons Attribution (CC BY) license (https:// creativecommons.org/licenses/by/ $4.0 /)$.
1 Centro de Estudios y de Investigación en Biotecnología (CIBIOT), Chemical Engineering Faculty, Universidad Pontificia Bolivariana, Cq. 1A 70-01, Building 11, Medellin 050031, Colombia; margarita.ramirez@upb.edu.co (M.R.-C.); leidy.rendon@upb.edu.co (L.R.-C.); carlos.ocampo@upb.edu.co (C.O.-L.)

2 Grupo Automática y Diseño A+D, Mechanical Engineering Faculty, Universidad Pontificia Bolivariana, Cq. 1A 70-01, Building 11, Medellin 050031, Colombia; paula.zapataramirez@upb.edu.co

* Correspondence: juan.arias@upb.edu.co

\begin{abstract}
Colombia has a diverse range of marine ecosystems in the coastal and insular areas of the Caribbean Sea and the Pacific Ocean. Seaweed research has focused mainly on the identification and taxonomic distribution of 628 species identified so far, mainly in the Caribbean Sea. Among the most widely cultivated genera of seaweeds in open-sea pilot systems in Colombia are Hydropuntia, Gracilaria, Hypnea, Kappaphycus, and Eucheuma. These genera have shown low yields as a consequence of high tissue fragility, epiphytism, sedimentation, and nitrogen deficiency. In addition, the evaluation of the biological activity of selected seaweed compounds has advanced considerably, focusing on their composition and their use for direct consumption by humans and animals. Despite the diversity of seaweeds, as well as certain technical and scientific advances, Colombia is still lagging behind other countries in seaweed exploitation, both in Latin America and worldwide. This current status raises the need to increase research, technological (agro-tech) appropriation, and the adoption of effective public policies that will boost algal businesses. In addition, seaweed cultivation could support the current blue economy transition in Colombia, which could eventually allow the country to enter the global seaweed market.
\end{abstract}

Keywords: agro-tech future trends; biodiversity; biological activity; Colombia; seaweed resources

\section{Introduction}

In recent years, the cultivation and marketing of seaweeds and their products worldwide have attracted growing attention, being valued at USD 5.9 billion in 2019, and expected to show an estimated compound annual growth rate (CAGR) of 9.1\% until 2027 [1]. This growth is largely based on applications of various seaweeds in the food, chemical, pharmaceutical, cosmetic, and energy industries [2,3].

Marine macroalgae, commonly known as seaweeds, are macroscopic, multicellular, photosynthetic eukaryotic organisms that can be classified into three taxonomic groups, i.e., Phaeophyceae (brown), Rhodophyta (red), and Chlorophyta (green) based on their characteristic pigmentation. It is estimated that the global diversity of all algae (micro and macro) is around 164,000 species [4], about 9800 of these are seaweeds [5], of which only $0.17 \%$ have been domesticated for commercial exploitation [6].

The most traditional uses of seaweeds comprise the manufacture of fertilizers/biostimulants since Roman times [7], animal feed since 45 BC [8,9], human nutrition, and source of medicinal compounds since the fourth century in Japan [10] and South America [11], and fuel production since 1940 [12,13]. Seaweeds are mainly used in the food industry as a source of hydrocolloids. Agars, alginates, and carrageenans are the main hydrocolloids obtained from red and brown algae [14]. In recent years, some seaweeds have been 
considered a source of natural bioactive compounds with potential nutraceutical [15-18], cosmeceutical [19-22], and pharmaceutical value [23-25].

Colombia is located in the northwestern region of South America, it is bordered by the Caribbean Sea to the north, Venezuela to the east, Brazil to the southeast, Ecuador and Peru to the south, the Pacific Ocean to the west, and Panama to the northwest (Figure 1).

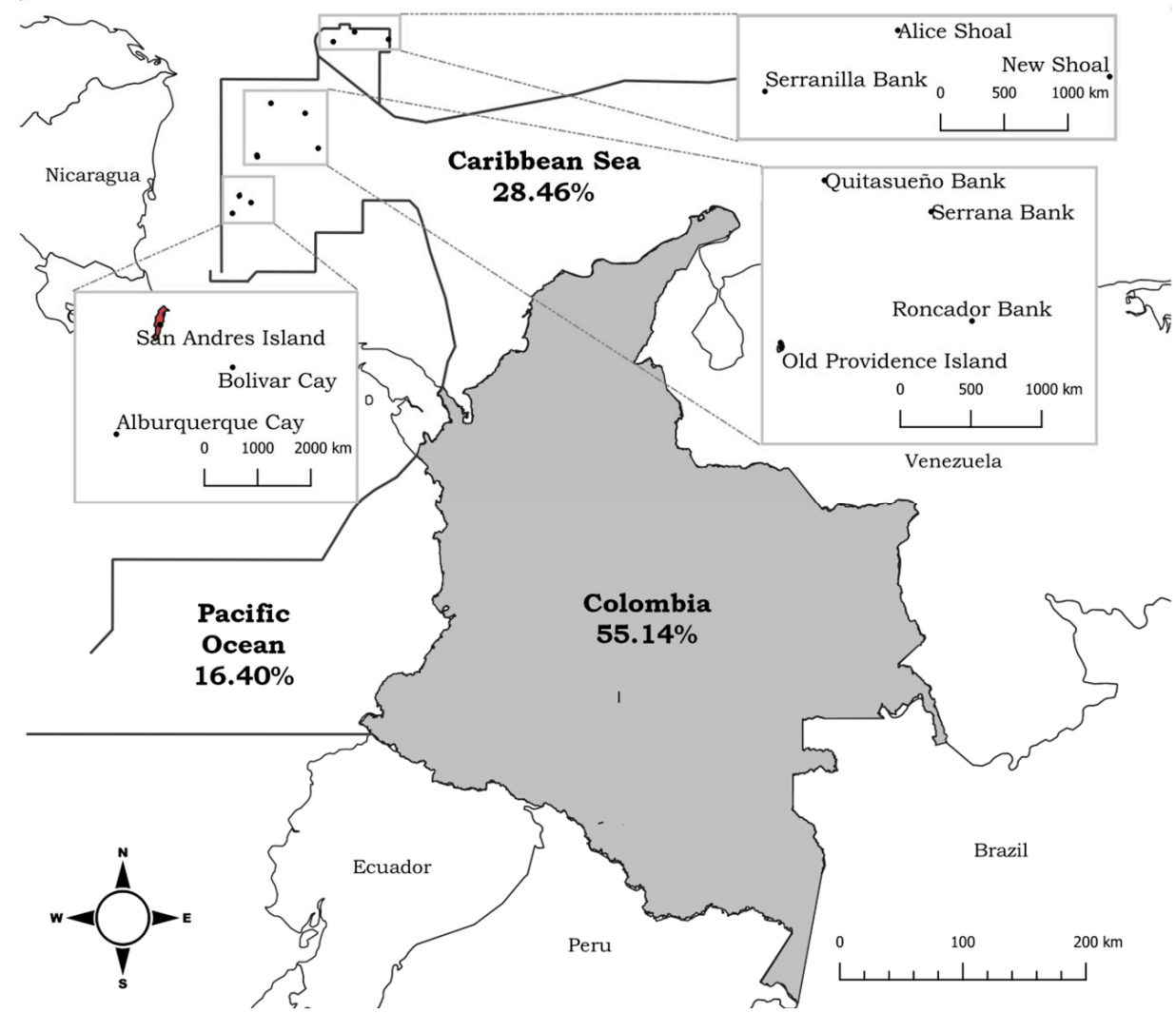

Figure 1. Continental and insular zone of the Caribbean and Colombian Pacific with the oceanic and terrestrial percentage of Colombian territory.

Colombia has a coastline with a length of $3531 \mathrm{~km}$ and approximately $892,102 \mathrm{~km}^{2}$ of surface area and coasts in both the Caribbean Sea and the Pacific Ocean, corresponding to $44 \%$ of the national territory [26]. The continental Caribbean region is made up of the coastal regions, as well as the insular area that includes San Andres, Old Providence, and Santa Catalina islands, in addition to seven cays as shown in Figure 1. In 2000, this insular zone was declared an International Seaflower Biosphere Reserve by the United Nations for Education, Science, and Culture $[27,28]$. The Pacific region includes the continental coasts, as well as the insular coasts of the Gorgona and Malpelo islands (Figure 1).

Colombia can be considered one of the South American countries with high marine biodiversity due to its diverse eco-regions distributed in both the Caribbean and the Pacific regions, previously described by Díaz and Acero [29]. These regions show heterogeneous climatic, oceanographic, geological, and biochemical characteristics, and contain a variety of environments such as beaches and rocky coasts, coral reefs, seagrass meadows, and mangrove forests, which harbor high biological diversity [30]. Seaweeds are part of this biological resource, integrating several ecosystems and contributing to their balance and ecological function.

This review updates the current status of knowledge on seaweeds in Colombia, compiling information regarding diversity, distribution, and research. In addition, particular species with biotechnological potential, for cultivation and extraction, are identified, as well as applications of their bioactive compounds. Finally, this review provides the basis for discussion regarding the potential of seaweeds for future applications in food, pharma- 
ceutical and cosmetic industries, which could lead to supporting a blue economy transition in Colombia.

\section{A Global View of Seaweed Use}

Worldwide seaweed production was estimated at 36 million tons (fresh weight) per year, equivalent to USD 14.85 billion. Of these, 97\% corresponds to seaweed from aquaculture and only $3 \%$ comes from harvesting/exploitation of wild populations [31]. Among the most productive regions are Asia with 99\% of worldwide production, led by China and Indonesia [32,33], followed by America and Europe [34]. Seaweed production is dominated by brown species such as Saccharina japonica and Undaria pinnatifida and by red species such as Pyropia spp., Kappaphycus alvarezii, K. striatus (as Eucheuma striatum), and Gracilaria spp. $[35,36]$. Latin America contributed only $1.3 \%$ of world seaweed production, of which $98 \%$ was obtained from wild harvest and only $2 \%$ from aquaculture. Chile contributed $88 \%$ of the seaweed harvested in Latin America [37], followed by Peru [38] and Mexico [39] with 4.1 and $3.7 \%$, respectively.

To date, several review articles have illustrated the current status of seaweed cultivation worldwide [35,40,41] and in Latin America [37,42], as well as a large number of applications of seaweeds and their compounds [23,43-48]. Figure 2 illustrates the growing trend over the last 20 years in the number of review articles related to seaweeds in indexed academic journals and databases such as PubMed, Science Direct, and Scopus. In the reviewed literature, Colombia does not appear in the statistics of research, harvesting, or cultivation of seaweed worldwide. This may be a consequence of (i) the lack of applied research and technology to establish open sea, land-based, or in vitro seaweed cultures, (ii) the absence of national phycologists to support these developments, and (iii) the lack of funding that has hindered the development of this economy.

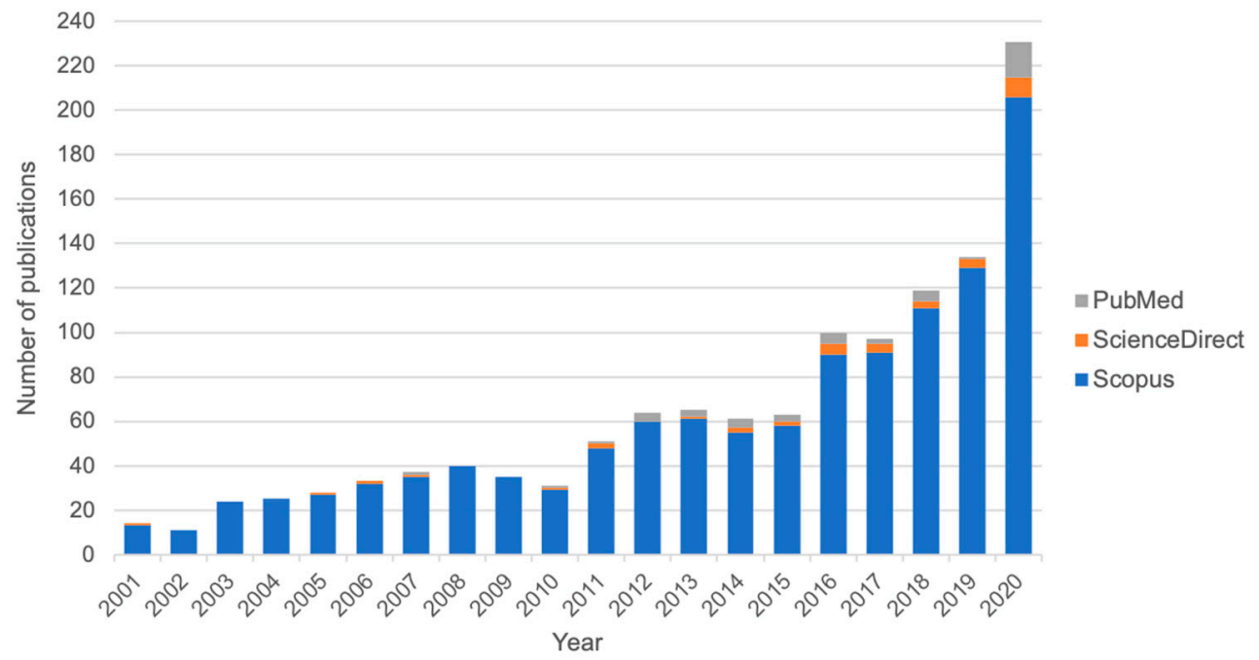

Figure 2. Number of publications of seaweed review articles in the databases. Source: Scopus, ScienceDirect, and PubMed. The figure shows the increasing number of publications on seaweed in recent years.

\section{Biodiversity of Marine Algae in Colombia}

The study of marine algae in Colombia dates back to 1799 with Humbolt and Bondpland's journey to the equinoctial regions [49] and continued throughout the 1960s and 1970s when Schnetter [50] contributed to the inventory and geographic distribution of species. Panizzo [51] also contributed preliminary studies of the chemical compositions of some algal species (e.g., Ulva rigida, Dictyota jamaicensis, Gracilaria mammillaris). Since then, research in this area has increased significantly. 
Recent results, obtained by expeditions [52] and independent research, carried out in the Seaflower Reserve of the Caribbean Sea, contributed to the identification, and listing of new marine algae (i.e., micro-, macroalgae, and cyanobacteria) for Colombia [53-59].

The most up-to-date list of marine algal species for Colombia was recently reported by Rincón-Díaz and Gavio [60], in the Information System on Marine Biodiversity (Sistema de Información sobre Biodiversidad Marina-SiBM). The authors compiled a list of 619 species taking into account new reports of seaweeds between 2003 and 2018 focused mainly on the Caribbean, as well as the list previously reported by Diaz and Díaz [61]. Furthermore, the list included an update of the species names following the recommendations of AlgaeBase (https:/ / www.algaebase.org) (accessed on 12 December 2021).

Since the listing of Rincón-Díaz and Gavio [60], nine new species have been reported from the Caribbean, five from the Seaflower International Biosphere Reserve [62], and four from the Rosario Islands [63].

Despite the progress made in the Caribbean Sea, the Pacific Ocean remains largely unexplored, mainly due to the difficulties of accessing certain oceanic zones, limiting the study of seaweeds to those associated with mangrove forests, which is the predominant ecosystem in the coastal areas of the Pacific $[64,65]$. The reports from the Pacific refer mainly to the work carried out by Schnetter and Bula-Meyer [66], Peña [67,68] and Rincón-Díaz et al. [69,70] who identified approximately 203 species, whose taxonomic distribution is shown in Table 1. To date, studies on marine algal biodiversity in neighboring regions of the Pacific have focused mainly on Panama, Costa Rica, Nicaragua, Honduras, and Guatemala [71].

Table 1. Distribution percentage of marine algae taxa in the Colombian Caribbean and Pacific. Adapted from Rincón-Díaz and Gavio [60].

\begin{tabular}{lcc}
\hline & Caribbean & Pacific \\
\hline Rhodophyta & $60 \%$ & $63 \%$ \\
Chlorophyta & $28 \%$ & $20 \%$ \\
Phaeophyceae & $12 \%$ & $17 \%$ \\
\hline
\end{tabular}

\section{Types of Seaweed Cultivation}

To have the necessary volume of commercially desirable seaweeds to supply growing worldwide demand, without overexploiting marine ecosystems due to over-exploitation, it is essential to establish optimal seaweed cultivation systems. Seaweed can be grown in open-sea areas (offshore and nearshore), land-based (or onshore), and even in integrated multi-trophic aquaculture systems.

\subsection{Open-Sea Cultivation}

Open-sea cultivation is characterized by being located at a certain distance from the coast where suitable cultivation conditions (temperature, nutrients, light, water movement) are guaranteed. Seaweeds can be grown on the seafloor attached to hard substrata or to floating on ropes, lines, or nets. This method has been successfully implemented in Asia [36], East Africa [72], and part of the US [35,73]. Among the most cultivated species are Saccharina japonica, Undaria pinnatifida, Pyropia/Porphyra spp., Kappaphycus alvarezii, Eucheuma striatum, and Gracilaria/Gracilariopsis spp. [36]. Installation, maintenance, and seeding of seaweeds in open-sea cultivation systems, although quite laborious, are low cost, making these systems a popular form of cultivation [74].

Among the main disadvantages of open-sea cultivation are that the structures and seaweeds are susceptible to adverse environmental conditions (tides, waves, and wind). As a result, these cultures must be developed extensively and be located in different geographical locations to mitigate environmental risk and be economically viable [75]. Another disadvantage is the fouling by macroscopic organisms (epiphytes) at different seasons of the year, which causes a large loss of biomass, as well as the impossibility of having year-round cultivation [74]. 


\subsection{Land-Based Cultivation}

Land-based cultivation takes place in closed systems (tanks, ponds, or raceways), where the supply of clean seawater and rigorous control of temperature, lighting, and nutrient availability, guarantee optimal growing conditions [75,76]. Land-based seaweed cultures may be installed anywhere in the world, preferably near the coast, where there is a constant supply of seawater and ideal climatic conditions for seaweed growth, and at a location close to the processing and manufacturing plant site [77].

Among the main advantages of land-based cultivation are (i) the possibility of using the same facilities for the cultivation of different seaweeds [75], (ii) stringent control of the quality and productivity of these cultures, (iii) the possibility to obtain different products by modifying only the nutrient input and cultivation conditions, without the need to work with genetically modified species, although the technology can be applied [77]. The high modularity of land-based cultivation allows starting with small units, where cultivation conditions can be optimized to scale up these cultures quickly and safely, enabling rapid commercial domestication of different seaweeds.

The main disadvantages of land-based cultivation are the high costs of building infrastructure and maintaining optimal growing conditions. Land and suitable water availability for land-based production are limited and, when available, often expensive [75].

The establishment of land-based seaweed cultures worldwide is mainly carried out by industrial research and development centers, such as AlgaPlus in Portugal [78], Seakura in Israel [79], Pacific Bio and PhycoHealth in Australia [80], Algas Chile [81], and Acadian Seaplants in Canada [82], among others.

To date, some of the few genera cultivated in land-based systems are Ulva [83-85], Chondrus [82], Palmaria [86,87], and Porphyra [77], but the increasing application and adaptation of these systems to other seaweed species will increase the number of products that could be offered in the global seaweed market.

\subsection{Integrated Multitrophic Aquaculture Systems (IMTA)}

IMTA is a feasible option to be implemented in both open sea and land-based systems by integrating the culture of animals fed in cages, (e.g., fish or shrimp), with extractive aquaculture, (e.g., algae and shellfish) [36]. The efficiency of these systems is based on the assimilation of excreted ammonium, phosphates, and $\mathrm{CO}_{2}$ by seaweeds, converting them into biomass [32]. This system achieves a cleaning and/or filtration process of the effluents, which can be recirculated to the ponds or discarded, without affecting the environment, creating a more balanced ecosystem [88]. IMTA can increase the long-term and overall sustainability and profitability by transforming the wastes of the main cultured species into subproducts as fertilizers, food, and energy, thereby adding further commercial and environmental value to the culture [89].

\section{Seaweed Cultivation Experiences in Colombia}

Although Colombia has a wide diversity in terms of macroalgal genetic resources [60], there is a low number of specimens in the areas where they are located. This could be associated with seasonality and environmental conditions that hinder the development of productive processes in the natural environment.

To date, some research has been conducted in the establishment of pilot seaweed cultivation in Colombia, both in the open sea and land-based as presented in Table 2. Some publications that provide a chronological account of experiences carried out in mariculture in Colombia stand out, e.g., Álvarez et al. [90], Molina and Álvarez [91] and Peña and Álvarez [92]. Much of the reported research was conducted by Foundations, Environmental Corporations, and other institutions, where the results obtained (undergraduate thesis, progress, and final reports) can be classified as grey literature [93-95] since they are not included in indexed databases and therefore access is difficult. 
Table 2. Seaweed species cultivated in Colombia.

\begin{tabular}{|c|c|c|c|c|}
\hline Specie & Region & $\begin{array}{c}\text { Type of } \\
\text { Culture }{ }^{1}\end{array}$ & $\mathrm{DGR}^{2}$ & Reference \\
\hline \multicolumn{5}{|l|}{ Rhodophyta } \\
\hline \multicolumn{5}{|l|}{ Order Gracilariales } \\
\hline Grateloupia sp. & Guajira & $\mathrm{B}, \mathrm{R}$ & - & [96] \\
\hline Gracilariopsis tenuifrons & Guajira & $\mathrm{B}, \mathrm{R}$ & 0.59 & [97] \\
\hline Gracilaria cervicornis & Guajira & $\mathrm{B}, \mathrm{R}$ & 0.44 & [96] \\
\hline $\begin{array}{l}\text { Gracilaropsis longissima } \\
\text { (as Gracilaria verrucosa) }\end{array}$ & Magdalena & B & - & [91] \\
\hline $\begin{array}{l}\text { Crassiphycus corneus } \\
\text { (as Hydropuntia cornea) }\end{array}$ & Guajira & $\mathrm{B}, \mathrm{R}$ & $0.97,0.51$ & {$[96,97]$} \\
\hline Kappaphycus alvarezii * & Guajira & $\mathrm{R}$ & 5.1 & [98] \\
\hline \multicolumn{5}{|l|}{ Order Gigartinales } \\
\hline Hypnea musciformis & $\begin{array}{l}\text { Guajira-Santa } \\
\text { Marta }\end{array}$ & $\mathrm{B}, \mathrm{R}$ & $2.66,-$ & {$[96,99]$} \\
\hline $\begin{array}{c}\text { Eucheumatopsis } \\
\text { isiformis (as Eucheuma } \\
\text { isiforme) }\end{array}$ & Guajira & $\mathrm{B}, \mathrm{R}$ & 1.58 & [97] \\
\hline $\begin{array}{l}\text { Order Halymeniales } \\
\text { Grateloupia filicina } \\
\text { Chlorophyta }\end{array}$ & Magdalena & - & - & [90] \\
\hline \multicolumn{5}{|l|}{ Order Bryopsidales } \\
\hline Caulerpa sertularioides & Nariño & $\mathrm{P}$ & 4.82 & [100] \\
\hline
\end{tabular}

Having access to this information is highly valuable because it covers what is being done beyond the academic sphere and reports both advances and difficulties at the national level. Therefore, it is necessary to look for strategies within these institutions to allow access to information more simply and effectively, granting the extrapolation of their experiences to future work and productive processes.

Among the most mentioned works are those of Delgadillo and Newmark [96] and Camacho and Montaña [99] who established cultures of Hypnea musciformis in the regions of La Guajira and Santa Marta, respectively. The environmental characteristics of both areas were similar in terms of temperature and salinity. The strong water movement at La Guajira together with the mechanical fragility of the species was responsible for the high loss percentages, which prevented the establishment of the cultures [96]. In Santa Marta, an average daily growth rate of $2.66 \%$ was reached; however, the authors do not mention the swell conditions in the area. This lack of specific information prevents any conclusion regarding the influence of environmental conditions on the viability of $H$. musciformis culture viability. The growth rate reported by Camacho, although lower, may be comparable to open-sea cultures developed in Bangladesh (3.2\%) [101] and, to a lesser extent in Brazil (5.7\%) [102] and India (7.6\%) [103] showing the potential of Santa Marta for the establishment of H. musciformis cultures. In the same way, Molina and Álvarez [91] and Rincones and Moreno [97] cultivated Gracilariopsis sp. in Atlántico and La Guajira, respectively. Of these works, only Rincones and Moreno reported average daily growth values of $0.6 \%$, a value that was considered low for the establishment of a productive culture in the study area. Considering that growth rates of $2.8 \%$ have been reported for net bag cultures of G. tenuifrons in Venezuela [104], 4.7\% and 8\% for rope [105] and net [106] cultures of G. longissimi in Spain, and 5\% in rope cultures of G. lemaneiformis in China [107], the results of Rincones and Moreno [97] indicate that, for the moment, suitable conditions for the cultivation of this species are not guaranteed.

The daily growth rate of the different species cultivated in Colombia was between 0.44 and $4.82 \%$ day $^{-1}$ (Table 2 ). These data show that there is great variability in the daily growth rates, which depends on the species and the cultivation conditions, including seasonal 
variation. Therefore, it is necessary to continue to determine the optimal conditions that allow the scaling up of seaweed cultivation in the coastal areas of Colombia.

In general terms, reports related to seaweed cultivation in Colombia provide limited information (e.g., description of the study areas and algal growth results), while specific and relevant factors associated with the cultivation conditions are missing. Therefore, a complete and integrated analysis of the seaweed cultivation field is challenging, and the decision-making process aimed at designing commercially successful seaweeds cultures is considerably impaired.

In the early 1990s, the Food and Agriculture Organization of the United Nations (FAO), in partnership with the von Humboldt Institute were looking for alternative productive activities for local Wayuu communities in the La Guajira Peninsula $[98,108,109]$. To that end, the FAO and the von Humboldt Institute introduced and established cultures of Kappaphycus alvarezii, through vegetative propagation. This species is widely cultivated in tropical regions of the world to produce carrageenan [110] and shows high growth rates compared to other cultivated species (Table 2). Cuban thalli as seedstock, which themselves originated from Venezuela, were used and an average growth rate between 5.1 and $6.5 \%$ day $^{-1}$ in floating rope systems was achieved. These cultures were characterized by a significant loss of plant material in the cultivation areas. The main causes of these losses were climatic (wind, temperature, rainfall), hydrological (current patterns) and biological (epiphytes) conditions [98].

The cultivation of K. alvarezii in Colombia was quite controversial as its introduction was considered troublesome by some Colombian seaweed researchers and phycologists interviewed in this study. The environmental impact studies necessary to assess the possible risks of the introduction of $K$. alvarezii as an invasive species of reef and seagrasses ecosystems, as previously reported in other coastal areas of the world [111-114] were lacking. In 2008, K. alvarezii was included in the list of invasive alien species in Colombia, (Resolution 848-2008 of the Ministry of Environment, Housing and Territorial Development).

Pilot seaweed cultivations have been conducted in coastal areas with environmental conditions similar to those of Colombia. Eucheuma spp., Gracilaria spp., and K. alvarezii are some of the species successfully cultivated in Belize [115,116] and Panama [117]. Nevertheless, there is no clear information about what was the successful approach used in these pilots. This makes it difficult to identify the lessons learned in these areas and the failures that are being committed at the national level, which should be explored in depth.

Up to this point, the present review shows that the results in extensive open sea cultures carried out in Colombia were characterized by low productivity and in the cases where good biomass growth was achieved, it was not possible to maintain it throughout the year, due to seasonality. The results indicated that the limited success of seaweed cultivation in the open sea seems to be related to the difficulty of taking in situ measurements and controlling the physical, chemical, and biological variables that affect culture yield and productivity.

Several other factors are involved in the establishment and productivity of seaweed cultures. Human activities, such as the increasing contamination of water bodies by domestic, industrial, and agro-industrial discharges, mining activities, as well as the emission of $\mathrm{CO}_{2}$ into the atmosphere, cannot be ignored. These are some of the major factors responsible for the environmental changes (e.g., alterations in the carbon cycle, stratification, eutrophication, increases in UVB radiation, surface temperatures, and decreases in $\mathrm{pH}$, among others) recorded in marine ecosystems [118-120]. Additionally, in Colombia, according to several interviews with highly regarded seaweed researchers, it was possible to identify that some of the main difficulties to establishing commercial seaweed cultures are the idiosyncrasy and socio-economic conditions of the communities.

Colombia has little or no experience in land-based cultivation, except for the laboratory work carried out by Mosquera and Peña [100] with Caulerpa sertularioides. This work was focused on the effect of salinity on algal growth while maintaining constant illumination, temperature, and nutrients, and optimal growth was achieved at a salinity of 
25 with artificial seawater. Nevertheless, the study did not provide any extra information regarding $C$. sertularioides cultivation, indicating the importance of studying the effect of other variables on the in vitro growth of this seaweed.

So far, this review indicates that despite some experiences of pilot-scale seaweed cultivation in Colombia, there is an opportunity to adopt technologies for land-based seaweed cultivation that are successful elsewhere, such as those of Seakura in Israel [79] and Acadian Seaplants in Canada [82], to trigger the potential application of this technology in the country.

\section{Applications of Seaweeds in Colombia}

The worldwide application of seaweeds in the food, pharmaceutical, cosmetic, and energy industries is based on the nutritional and biological value of their content of minerals, vitamins, carbohydrates, proteins, and fatty acids [121]. In Colombia, the applications of seaweeds are mainly focused on: (i) the study of their composition [90], both for direct consumption or fertilizer production, (ii) evaluation of the biological activity of extracts, and (iii) the extraction of polysaccharides and pigments.

\subsection{Fertilizers}

The most feasible applications of seaweed comprise the field of fertilizers; due to their contribution of minerals, nutrients [122] and their activation in the production of growth regulators. Bula-Meyer [123] reviewed several applications of seaweed in Colombian agriculture showing their potential to be used as fertilizers. His work focused on Sargassum, highlighting the nutritional composition as well as the effect of derived products on important plant crops variables such as fruit aging, frost resistance, and nutrient absorption.

\subsection{Biological Activity}

The increasing demand for products with the biological activity of importance to medicine (e.g., antimicrobial, antiviral, antitumor) has promoted the discovery and production of new compounds by chemical synthesis or extraction and purification from natural sources. The biological activity of various seaweeds in Colombia has been focused on the evaluation of antimicrobial, cytotoxic, and antioxidant activity. The main findings of biological activities from seaweed extracts collected in Colombia are reported in Table 3.

Table 3. Biological activities of seaweed identified in Colombia.

\begin{tabular}{ccc}
\hline Species & Biological Activity & Reference \\
\hline Rhodophyta & & \\
Order Gelidiales & & \\
Gelidiella acerosa & Cytotoxic & {$[124]$} \\
Order Corallinales & & \\
Amphiroa fragilissima & Cytotoxic & {$[124]$} \\
Order Gracilariales & & \\
Gracilaria mammillaris & Antioxidant & {$[125]$} \\
Order Gigartinales & & \\
Hypnea musciformis & Antibacterial-Phenolic and & {$[126,127]$} \\
Order Ceramiales & steroidal compounds & \\
Digenea simplex & & {$[124]$} \\
Laurencia sp. & Cytotoxic & {$[128]$} \\
Laurencia microcladia & Antioxidant & {$[129,130]$} \\
Chlorophyta & Antibacterial & \\
Order Ulvales & & {$[126]$} \\
Ulva sp. (as Enteromorpha sp.) & & {$[126,128]$} \\
Order Bryopsidales & Antibacterial & {$[124]$} \\
Caulerpa mexicana & & \\
C. sertularioides & Antibacterial-Antioxidant & Cytotoxic \\
\hline
\end{tabular}


Table 3. Cont.

\begin{tabular}{ccc}
\hline Species & Biological Activity & Reference \\
\hline Ochrophyta & & \\
Order Dictyotales & & \\
Dictyota bartayresiana & Antibacterial-Feeding inhibitor & {$[129,130]$} \\
Dictyota pulchella & Antibacterial-Cytotoxic- & {$[129,130]$} \\
Dictyota sp. & Feeding & inhibitor \\
Padina boergesenii & Antioxidant & {$[128]$} \\
Order Fucales & Antibacterial & {$[129,130]$} \\
Sargassum cymosum & Antibacterial-Cytotoxic- & {$[124,128,129]$} \\
Sargassum sp. & Feeding inhibitor & {$[128]$} \\
Sargassum schnetteri (as & Antioxidant & {$[129]$} \\
Cladophyllum schnetteri) & Feeding inhibitor & \\
\hline
\end{tabular}

Antimicrobial activity assays focus on susceptibility testing of pathogenic microorganisms (e.g., bacteria and fungi) in the presence of potential compounds of interest. Studies of antimicrobial activity in Colombia date back to the 1970s, when Nuñez et al. [131] evaluated the antibacterial activity of extracts obtained from the algae Halimeda opuntia, Ulva lactuca, Gracilaria mammillaris, and Agardhiella subulata (as Agardhiella tenera) collected on the Atlantic coast. The results of this work are incomplete, only mentioning that $H$. opuntia and $U$. lactuta did not exhibit antimicrobial activity, which makes it difficult to make decisions and extrapolate the results. Arteaga and De Silvestri [126] complemented Nuñez's work with new extraction techniques, including the study of the effects of seasonal variability and $\mathrm{pH}$. The authors reported a higher antimicrobial activity of Ulva sp. (as Enteromorpha sp.), Hypnea musciformis, and Caulerpa mexicana extracts, prepared in phosphate buffer (10\%) and $\mathrm{pH}$ of 6.8 , as well as the variability of the compounds obtained as a function of seasonality.

Similarly, Martínez et al. [128] evaluated the antimicrobial activity of methanolic extracts of eight seaweeds on Gram-positive (Staphylococcus aureus and Bacillus cereus) and Gram-negative (Escherichia coli) bacteria. The results indicated that extracts from two species of Dictyota showed activity against $S$. aureus and B. cereus. Padina boergesenii showed activity against $B$. cereus, and finally Laurencia microcladia against $S$. aureus. The extracts of all these algae only showed activity on Gram-positive bacteria. The lack of activity on Gram-negative bacteria may be related to masking by other compounds [132] or to the non-production of compounds that act on these bacteria.

Regarding cytotoxic activity tests, these tests evaluate damage at the cellular level either sublethal (e.g., decreased cell proliferation) or lethal (e.g., apoptosis or autophagy). Seaweed cytotoxic activities have been evaluated in different cellular systems such as fertilized sea urchin (Lytechinus variegatus) eggs [129], colon cancer cells (HT29) [124], and human myeloid leukemia cells (Jurkat) [133].

The methanolic seaweed extracts obtained by Martínez et al. [130] showed a low cytotoxic activity as no retarding effects were observed in the mitotic processes in fertilized sea urchin eggs [129]. These results, although preliminary, indicated that the evaluated extracts could be used without the risk of generating cell damage mainly at the level of cell division and proliferation, which is a desirable property for algal-derived materials used in cosmetic products.

Methanolic extracts of six seaweeds (Amphiroa fragilissima, Gelidiella acerosa, Dichotomaria obtusata, Dictyota fasciola, Sargassum cymosum, and Caulerpa sertularioides) [124], as well as different fractions of the ethanolic extract of Digenia simplex [133,134], showed a potent cytotoxic effect on colon cancer cells and human myeloid leukemia cell line (Jurkat), respectively. The cytotoxic activity occurred as a consequence of a blockage of the mitotic phase (antimitotic activity) which could activate the process of programmed cell death [124]. This antimitotic activity could be a more effective strategy than those 
compounds that try to interrupt the progression of cell proliferation (e.g., Colcemid ${ }^{\circledR}$ ) making these extracts potential antitumor agents.

Concerning the antioxidant capacity and the content of phenolic compounds, ethanolic extracts from Caulerpa mexicana, Laurencia sp., Sargassum sp., Dictyota sp. and Sargassum cymosum [128], Hypnea musciformis [127], and Gracilaria mammillaris [125], among other species, have been studied. The results indicated that the antioxidant capacity observed was mainly related to the production of phenolic compounds. Amongst the species studied, the following were highlighted: S. cymosum for its concentration of phenolic compounds $(0.822 \mathrm{mg}$ acid gallic equivalent/g extract), H. musciformis for its antioxidant activity (550 $\mu \mathrm{mol}$ Trolox equivalent/L), and G. mammillaris which showed a high level of antioxidant activity in edible oils, inhibiting $42.1 \%$ of thiobarbituric acid reactive substance (TBARS) formation in accelerated oxidation assays. These results are preliminary as they could be improved by the implementation of more effective extraction techniques [43], as well as the fractionation of the extracts [135], which would increase the antioxidant activity of the extracts and project the extracts obtained from seaweeds as a new natural source of antioxidant compounds in the food and cosmeceutical industry.

\subsection{Polysaccharides and Pigments}

Another important topic of the research in seaweed application is the production of polysaccharides and pigments, among which: agars, alginates, carrageenans, and fucoxanthins, stand out.

Studies related to polysaccharides and pigments focus mainly on the evaluation of the extraction processes and how they affect variables such as gelation times, viscosity, gel strength, and absorption capacity. Table 4 shows some of the polysaccharides and pigments extracted from seaweeds in Colombia.

Table 4. Polysaccharides and pigments extracted from seaweeds in Colombia.

\begin{tabular}{lll}
\hline Species & Extract/Compound & Reference \\
\hline $\begin{array}{c}\text { Rhodophyta } \\
\text { Order Gracilariales } \\
\text { Gracilariopsis longissima } \\
\text { (as Gracilaria verrucosa) } \\
\text { Gracilariopsis tenuifrons }\end{array}$ & Agar-agar & \\
Agar and carrageenan & {$[136]$} \\
Ochrophyta & & {$[137]$} \\
Order Fucales & Alginate & \\
Sargassum sp. & Alginate & \\
S. cymosum & Fucoxanthin & {$[138]$} \\
S. filipendula & Fucoxanthin \\
Surbinaria spp. & Folyceratium & {$[138]$} \\
Order Dictyotales & Fucoxanthin & {$[139]$} \\
Dictyota caribaea & Fucoxanthin & {$[139]$} \\
D. pinnatifida & & {$[139]$} \\
\end{tabular}

Among the works with polysaccharides, the production of agar from Gracilariopsis longissima (as Gracilaria verrucosa) was favored by the extraction under acidic conditions, obtaining better gelation times, color, and texture [136]. The production of alginate from Sargassum sp. and Sargassum cymosum showed low viscosity (16.95 mPa.s) but high gel strength $\left(787.5 \mathrm{~g} \mathrm{~cm}^{-2}\right)$ [138]. These results are attractive, for the application of these types of alginates in raw materials requiring high gel strength whilst maintaining good porosity. The extraction of kappa and beta carrageenan polysaccharides from Gracilariopsis tenuifrons showed good absorption in the UVB and UVA range, giving them a broad spectrum of photoprotection $[137,140]$.

Concerning pigment production, Restrepo [139] studied the fucoxanthin content in brown seaweeds, e.g., Dictyota, Sargassum, Spatoglossum, and Turbinaria. The highest fucox- 
anthin content (10.03 $\left.\mathrm{mg} \mathrm{g}^{-1}\right)$ was reported for the extract of Sargassum filipendula, followed by Dictyota caribaea $\left(8.36 \mathrm{mg} \mathrm{g}^{-1}\right)$ and Dictyota pinnatifida $\left(6.77 \mathrm{mg} \mathrm{g}^{-1}\right)$. According to the authors, the high values of fucoxanthin may be related to the environmental conditions of the areas where the collections were made, being higher in those where exposure to light was greatest since this compound fulfills functions of light capture, as well as protection against oxidative stress generated by UV radiation.

Finally, Vargas [141] is one of the few works found that elaborated products using seaweed extracts and also evaluates their biological activity. Vargas developed cosmetic products such as moisturizing cream, sunscreen, and gel mask, with the addition of Hypnea musciformis ethanolic extracts. Results showed an improvement in physicochemical and microbiological properties, as well as UV absorption, as compared to the respective controls.

As previously indicated, the application of seaweed in Colombia has focused on chemical composition, biological activity, and extraction of polysaccharides and pigments. While among the most unexplored fields are biofuels and direct human consumption. This situation could be related to the fact that their application in these sectors requires high quantities of biomass, which has not been possible to obtain despite the resources that have been used in the few pilot cultures developed in the country.

Regarding seaweeds for human consumption, there is less interest, since these have not been part of the Colombian diet. Consequently, this situation could conduct to greater difficulties for its implementation in the short and medium-term. However, considering the transformation of the agri-food industry that focuses on achieving healthier and more environmentally sustainable foods, new global food trends have positioned selected seaweeds as candidates to lead this transformation [142-144]. These trends could generate new food proposals that seek to revive and reinvent cuisine with seaweed as it has been developed in other areas of the world $[145,146]$.

The integration of suitable seaweeds in the Colombian economy would contribute to the implementation of a transition towards a blue economy as one of the highest priority goals included in Colombia Potencia Bioceánica Sostenible 2030 [147] as well as with the objectives of the United Nations Development Programme for Colombia [148].

\section{Future Prospects}

Our main findings indicated that research on seaweeds in Colombia is at a preliminary stage. In recent years, there has been an increasing number of publications focused on taxonomic identification, biological evaluation of extracts, as well as the establishment of a few pilot cultures (Figure 3).

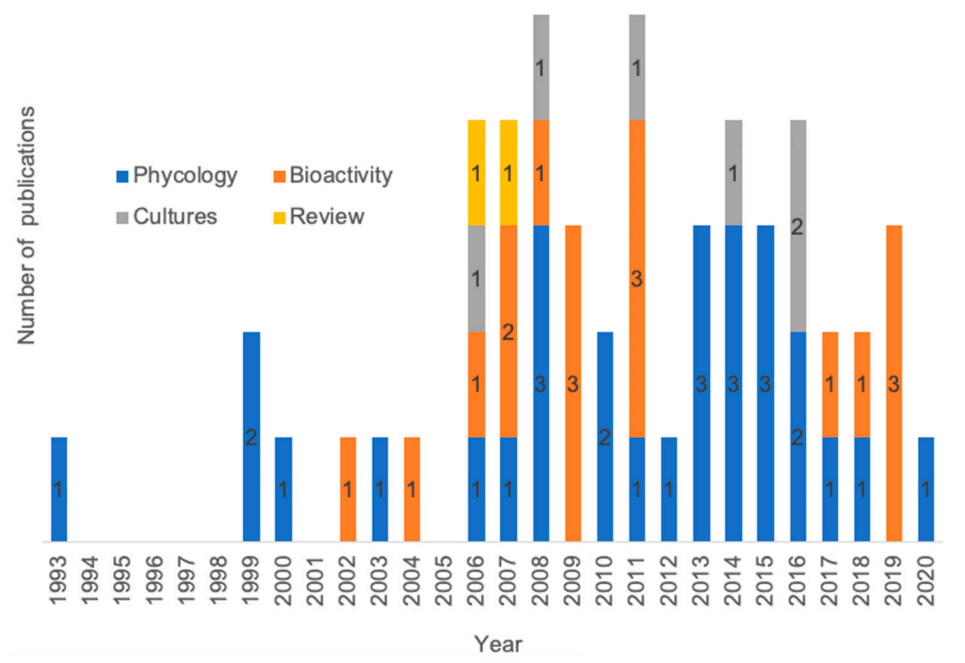

Figure 3. Trends in research on seaweed species in Colombia during 1993-2020. The numbers inside each bar indicate the number of publications per year about the type of studies conducted. Source: Prepared by the authors. 
Despite these advances, Colombia lags far behind countries such as Chile, Brazil, Peru, and Mexico, which are the Latin American references worldwide in the exploitation of seaweeds [37]. Although these countries have different environmental conditions, compared to those of Colombia, that may allow the cultivation of certain species of seaweed, they have established clear policies regarding the management of their marine resource [42]. In addition, the development and implementation of large-scale, open sea, seaweed cultivation technologies have allowed the expansion of its industry.

Although Colombia has a National Plan for the development of Sustainable Aquaculture [149], this does not include seaweed cultivation. It is necessary, to create clear and simple public policies that allow responsible access to genetic resources as well as the permits for the establishment of sustainable seaweed cultures in coastal and open sea areas. This will serve to increase basic and applied research identifying seaweed species with potential in terms of biologically active compounds and their ability to be cultivated in open sea or land-based systems. The next steps would be: (i) the development of more efficient and environmentally friendly technologies (agro-tech) that would allow for the cultivation, extraction, and purification of seaweeds and their active compounds [150]; (ii) the implementation and adaptation of already existing and successful technologies in land-based seaweed cultivation $[79,151]$. The latest step could contribute to overcoming the difficulties related to seasonality and the lack of control of relevant variables for the cultivation of seaweed species in Colombia. This would allow more rapid development of the seaweed national industry. The above requires the participation of different stakeholders such as investors, the industrial and governmental sectors. By working in conjunction with local communities it could be possible to ensure the necessary capital to provide stability to algal projects, guaranteeing continuous and homogeneous production, as well as high-quality standards in the medium and long term. In this way, it will be possible to develop and support the current transition towards a blue economy in Colombia.

Author Contributions: Conceptualization, J.P.A.-E., P.A.Z.-R., M.R.-C. and C.O.-L.; methodology, J.P.A.-E., M.R.-C. and C.O.-L.; validation, J.P.A.-E., P.A.Z.-R., M.R.-C. and C.O.-L.; formal analysis, J.P.A.-E.; investigation, J.P.A.-E., P.A.Z.-R. and M.R.-C.; resources, M.R.-C. and P.A.Z.-R.; data curation, J.P.A.-E.; writing original draft preparation, J.P.A.-E., P.A.Z.-R., M.R.-C. and C.O.-L.; writing-review and editing, J.P.A.-E., P.A.Z.-R., M.R.-C. and C.O.-L.; visualization, J.P.A.-E. and C.O.-L.; supervision, M.R.-C. and L.R.-C.; project administration, M.R.-C.; funding acquisition, M.R.-C. All authors have read and agreed to the published version of the manuscript.

Funding: This research was funded by Universidad Pontificia Bolivariana through the Centro de Investigación para el Desarrollo y la Innovación (CIDI).

Institutional Review Board Statement: Not applicable.

Informed Consent Statement: Not applicable.

Acknowledgments: Juan Pablo Arias-Echeverri acknowledges financial support from Minciencias Colombia: Fondo Nacional para la Ciencia, la Tecnología y la Innovación "Francisco José de Caldas" (Grant 848-2019).

Conflicts of Interest: The authors declare no conflict of interest. The funders had no role in the design of the study; in the collection, analyses, or interpretation of data; in the writing of the manuscript, or in the decision to publish the results.

\section{References}

1. Grand View Research. Global Commercial Seaweeds Market Size Report, 2020-2027. Report Overview. 2020. Available online: https:/ / www.grandviewresearch.com/industry-analysis/commercial-seaweed-market (accessed on 20 November 2020).

2. Cioš, A.M.; Jerković, I.; Molnar, M.; Šubarić, D.; Jokić, S. New trends for macroalgal natural products applications. Nat. Prod. Res. 2019, 35, 1180-1191. [CrossRef]

3. Wei, N.; Quarterman, J.; Jin, Y.-S. Marine macroalgae: An untapped resource for producing fuels and chemicals. Trends Biotechnol. 2013, 31, 70-77. [CrossRef] [PubMed]

4. Algaebase: Listing the World's Algae. Available online: http://www.algaebase.org/ (accessed on 12 November 2021).

5. Pereira, L. Macroalgae. Encyclopedia 2021, 1, 17. [CrossRef] 
6. Duarte, C.M.; Marbá, N.; Holmer, M. Rapid domestication of marine species. Science 2007, 316, 382-383. [CrossRef]

7. Pereira, L.; Cotas, J. Historical use of seaweed as an agricultural fertilizer in the european atlantic area. In Seaweeds as Plant Fertilizer, Agricultural Biostimulants and Animal Fodder; Pereira, L., Bahcevandziev, K., Joshi, N., Eds.; CRC Press: Boca Raton, FL, USA, 2019; pp. 1-23.

8. Chapman, V.J.; Chapman, D.J. Seaweeds and Their Uses, 3rd ed.; Springer: Dordrecht, The Netherlands, 1980.

9. Newton, L. Animal and human nutrition from seaweed resources in Europe: Uses and potential. In Seaweed Utilization; Sampson Low: London, UK, 1951; pp. 31-57.

10. Kılınç, B.; Cirik, S.; Turan, G.; Tekogul, H.; Koru, E. Seaweeds for food and industrial applications. In Food Industry, 1st ed.; Muzzalupo, I., Ed.; IntechOpen: London, UK, 2013.

11. Dillehay, T.M.; Ramírez, C.; Pino, M.; Collins, M.B.; Rossen, J.; Pino-Navarro, J.D. Monte verde: Seaweed, food, medicine, and the peopling of South America. Science 2008, 9, 784-786. [CrossRef]

12. Gao, G.; Burgess, J.G.; Wu, M.; Wang, S.; Gao, K. Using macroalgae as biofuel: Current opportunities and challenges. Bot. Mar. 2020, 63, 355-370. [CrossRef]

13. Kelly, M.S.; Dworjanyn, S. The Potential of Marine Biomass for Anaerobic Biogas Production. The Crown Estate: London, UK, 2008. Available online: https:/ / arpa-e.energy.gov/sites/default/files/The\%20Potential\%20of\%20Marine \%20Biomass\%20for\% 20Anaerobic\%20Biogas\%20Production\%202008.pdf (accessed on 20 August 2020).

14. Qin, Y. Production of seaweed-derived food hydrocolloids. In Bioactive Seaweeds for Food Applications: Natural Ingredients for Healthy Diets; Qin, Y., Ed.; Elsevier: Amsterdam, The Netherlands, 2018; pp. 53-69.

15. Coas, J.; Leandro, A.; Pacheco, D.; Gonçalves, A.M.M.; Pereira, L. A comprehensive review of the nutraceutical and therapeutic applications of red seaweeds (Rhodophyta). Life 2020, 10, 19. [CrossRef]

16. Ganesan, A.R.; Tiwari, U.; Rajauria, G. Seaweed nutraceuticals and their therapeutic role in disease prevention. Food Sci. Hum. Wellness 2019, 8, 252-263. [CrossRef]

17. Shannon, E.; Abu-Ghannam, N. Seaweeds as nutraceuticals for health and nutrition. Phycologia 2019, 58, 563-577. [CrossRef]

18. Tanna, B.; Mishra, A. Nutraceutical potential of seaweed polysaccharides: Structure, bioactivity, safety, and toxicity. Compr. Rev. Food Sci. Food Saf. 2019, 18, 817-831. [CrossRef]

19. Couteau, C.; Coiffard, L. Seaweed application in cosmetics. In Seaweed in Health and Disease Prevention; Fleurence, J., Levine, I., Eds.; Elsevier: Amsterdam, The Netherlands, 2016; pp. 423-441.

20. Mrais, T.; Cotas, J.; Pacheco, D.; Pereira, L. Seaweeds compounds: An ecosustainable source of cosmetic ingredients? Cosmetics 2021, 8, 8. [CrossRef]

21. Pereira, L. Seaweeds as source of bioactive substances and skin care therapy-cosmeceuticals, algotheraphy, and thalassotherapy. Cosmetics 2018, 5, 68. [CrossRef]

22. Thomas, N.V.; Kim, S.-K. Beneficial effects of marine algal compounds in cosmeceuticals. Mar. Drugs 2013, 11, 146-164. [CrossRef] [PubMed]

23. Rengasamy, K.R.R.; Mahomoodally, M.F.; Aumeeruddy, M.Z.; Zengin, G.; Xiao, J.; Kim, D.H. Bioactive compounds in seaweeds: An overview of their biological properties and safety. Food Chem. Toxicol. 2020, 135, 111013. [CrossRef]

24. Siahaan, E.A.; Pangestuti, R.; Kim, S.-K. Seaweeds: Valuable ingredients for the pharmaceutical industries. In Grand Challenges in Marine Biotechnology; Rampelotto, P.H., Trincone, A., Eds.; Springer: Cham, Switzerland, 2018; pp. 49-95.

25. Smit, A.J. Medicinal and pharmaceutical uses of seaweed natural products: A review. J. Appl. Phycol. 2004, 16, 245-262. [CrossRef]

26. Informe del Estado de los Ambientes Marinos y Costeros en Colombia. 2017. Available online: http://www.invemar.org.co/ documents/10182/14479/IER_2017_baja_Final.pdf/76690566-f6e1-4610-906f-1c49c610b2c8 (accessed on 20 October 2020).

27. Comisión Colombiana del Océano. Reserva de Biósfera Seaflower. Available online: http://www.cco.gov.co/la-reserva.html (accessed on 3 October 2020).

28. Seaflower Biosphere Reserve. Available online: https:/ / en.unesco.org/biosphere/lac/seaflower (accessed on 20 March 2020).

29. Díaz, J.M.; Acero, A. Marine biodiversity in Colombia: Achievements, status of knowledge, and challenges. Gayana 2003, 67, 261-274. [CrossRef]

30. Márquez, G. Biodiversidad marina: Aproximación con referencia al Caribe. In Ecosistemas Estratégicos y Otros Estudios de Ecología Ambiental; Fondo FEN: Bogotá, Colombia, 1996; pp. 67-102.

31. Cai, J.; Lovatelli, A.; Aguilar-Manjarrez, J.; Cornish, L.; Dabbadie, L.; Desrochers, A.; Diffey, S.; Garrido Gamarro, E.; Geehan, J.; Hurtado, A.; et al. Seaweeds and microalgae: An overview for unlocking their potential in global aquaculture development. In FAO Fisheries and Aquaculture Circular No. 1229; FAO: Rome, Italy, 2021.

32. Gacía, S.; Leandro, A.; Cotas, C.; Cotas, J.; Marques, J.C.; Pereira, L.; Gonçalves, A.M.M. The evolution road of seaweed aquaculture: Cultivation technologies and the industry 4.0. Int. J. Environ. Res. Public Health 2020, 17, 6528. [CrossRef]

33. Mazarrasa, I.; Olsen, Y.S.; Mayol, E.; Marbà, N.; Duarte, C.M. Global unbalance in seaweed production, research effort and biotechnology markets. Biotechnol. Adv. 2014, 32, 1028-1036. [CrossRef]

34. Dos Santos Fernandes De Araujo, R. Brief on algae biomass production. In JRC Publications Repository JRC118214; European Commission: Brussels, Belgium, 2019.

35. Buchmann, A.H.; Camus, C.; Infante, J.; Neori, A.; Israel, A.; Hernández-González, M.C.; Pereda, S.V.; Gomez-Pinchetti, J.L.; Golberg, A.; Tadmor-Shalev, N.; et al. Seaweed production: Overview of the global state of exploitation, farming and emerging research activity. Eur. J. Phycol. 2017, 52, 391-406. [CrossRef] 
36. Kim, J.K.; Yarish, C.; Hwang, E.K.; Park, M.; Kim, Y. Seaweed aquaculture: Cultivation technologies, challenges and its ecosystem services. Algae 2017, 32, 1-13. [CrossRef]

37. Alemañ, A.E.; Robledo, D.; Hayashi, L. Development of seaweed cultivation in Latin America: Current trends and future prospects. Phycologia 2019, 58, 462-471. [CrossRef]

38. Avila-Peltroche, J.; Padilla-Vallejos, J. The seaweed resources of Peru. Bot. Mar. 2020, 63, 381-394. [CrossRef]

39. Vázquez-Delfín, E.; Freile-Pelegrín, Y.; Pliego-Cortés, H.; Robledo, D. Seaweed resources of Mexico: Current knowledge and future perspectives. Bot. Mar. 2019, 62, 275-289. [CrossRef]

40. Ferdouse, F.; Holdt, L.S.; Smith, R.; Murúa, P.; Yang, Z. The Global Status of Seaweed Production, Trade and Utilization; FAO Globefish Research Programme: Rome, Italy, 2018; Volume 124, p. 120.

41. Shobika, U.; Chrispin, L.C.; Santhiya, A.V. Global status of mariculture. Biotica Res. Today 2020, 2, 618-621.

42. Hayashi, L.; Bulboa, C.; Kradolfer, P.; Soriano, G.; Robledo, D. Cultivation of red seaweeds: A latin american perspective. J. Appl. Phycol. 2013, 26, 719-727. [CrossRef]

43. Cotas, J.; Leandro, A.; Monteiro, P.; Pacheco, D.; Figueirinha, A.; Goncallves, A.M.M.; Jorge Da Silva, G.; Pereira, L. Seaweed phenolics: From extraction to applications. Mar. Drugs 2020, 18, 384. [CrossRef]

44. Hentati, F.; Tounsi, L.; Djomdi, D.; Pierre, G.; Delattre, C.; Ursu, A.V.; Fendri, I.; Abdelkafi, S.; Michaud, P. Bioactive polysaccharides from seaweeds. Molecules 2020, 25, 3152. [CrossRef]

45. Jesumani, V.; Du, H.; Aslam, M.; Pei, P.; Huang, N. Potential use of seaweed bioactive compounds in skincare-A review. Mar. Drugs 2019, 17, 688. [CrossRef]

46. Lopez-Santamaria, A.; Miranda, J.M.; Mondragon, A.D.C.; Lamas, A.; Cardelle-Cobas, A.; Franco, C.M.; Cepeda, A. Potential use of marine seaweeds as prebiotics: A review. Molecules 2020, 25, 1004. [CrossRef]

47. Pimentel, F.B.; Alves, R.C.; Rodrigues, F.; Oliveira, M.B.P.P. Macroalgae-derived ingredients for cosmetic industry-An update. Cosmetics 2018, 5, 2. [CrossRef]

48. Rosa, G.P.; Tavares, W.R.; Sousa, P.M.C.; Pagès, A.K.; Seca, A.M.L.; Pinto, D.G.C.A. Seaweed secondary metabolites with beneficial health effects: An overview of successes in in vivo studies and clinical trials. Mar. Drugs 2020, 18, 8. [CrossRef] [PubMed]

49. Acevedo, G. Las algas marinas colombianas y su distribucion geografica. Rev. Acad. Colomb. Cienc. Exactas Fís. Nat. 1968, 13, 237-257.

50. Schnetter, R. Beitrag zur kenntnis der algenflora an der Kolumbianischen küste der karibischen see. Bol. Investig. Mar. Costeras 1969, 30, 49-57. [CrossRef]

51. Panizzo, L. Evaluación del contenido de nitrógeno y de aminoácidos totales en algunas especies de algas marinas pertenecientes a la región del Magdalena, Colombia. Rev. Acad. Colomb. Cienc. 1976, 14, 31-36.

52. Comisión Colombiana del Océano. Plan de Expediciones Científicas. Available online: http://www.cco.gov.co/plan-deexpediciones-cientificas.html (accessed on 3 October 2020).

53. Albis, M.R.; Gavio, B. Notes on marine algae in the international biosphere reserve seaflower, caribbean colombian I: New records of macroalgal epiphytes on the seagrass Thalassia testudinum. Bot. Mar. 2011, 54, 537-543. [CrossRef]

54. Albis, M.R.; Gavio, B. Notes on the marine algae of the international biosphere reserve seaflower, caribbean colombia IV: New records of macroalgal epiphytes on the seagrass Thalassia testudinum. Bol. Investig. Mar. Cost 2015, 44, 55-69. [CrossRef]

55. Gavio, B.; Cifuentes-Ossa, M.A.; Wynne, M.J. Notes on the marine algae of the international biosphere reserve seaflower, caribbean Colombia V: First study of the algal flora of quitasueño bank. Bol. Investig. Mar. Cost 2015, 44, 117-126. [CrossRef]

56. Reyes-Gómez, V.P.; Gavio, B. Notes on the marine algae of the international biosphere reserve seaflower, Caribbean Colombia VI: New records of Phaeophyceae from old providence and Santa Catalina. Acta Biol. Colomb. 2017, 22, 238-241. [CrossRef]

57. Reyes-Gómez, V.P.; Gavio, B.; Velasquez, H. Notes on the marine algae of the international biosphere reserve seaflower, caribbean Colombia III. New records of Cyanophyta. Nova Hedwig. 2013, 97, 349-360. [CrossRef]

58. Rincón-Díaz, M.N.; Gavio, B.; Wynne, M.J.; Santos-Martínez, A. First record of the red alga Griffithsia capitata (Ceramiales, Rhodophyta) in the southwestern Caribbean Sea, Western Atlantic. Mar. Biodivers. Rec. 2016, 9, 537. [CrossRef]

59. Rincón-Díaz, M.N.; Gavio, B.; Wynne, M.J.; Santos-Martínez, A. Notes on marine algae in the international biosphere reserve seaflower, caribbean Colombia, VII: Additions to the benthic flora of San Andrés Island. Caldasia 2018, 40, 97-111. [CrossRef]

60. Rincón-Díaz, M.N.; Gavio, B. Diversidad de Macroalgas Marinas del Caribe Colombiano, v2.8; Instituto de Investigaciones Marinas y Costeras-Invemar: Santa Marta, Colombia, 2020.

61. Diaz, G.; Díaz, M. Diversity of benthic marine algae of the Colombian atlantic. Biota Colomb. 2003, 4, 203-246. [CrossRef]

62. Reyes-Gómez, V.P.; Velasquez, H.; Gavio, B. Notes on the marine algae of the international biosphere reserve seaflower, Caribbean Colombia VIII: New records of red algae (Rhodophyta) from San Andres, Old Providence, and Saint Cataline, Colombia. Acta Bot. Mex. 2021, 128, e1848. [CrossRef]

63. Salazar-Forero, C.E.; Gavio, B.; Wynne, M.J. Macroalgae associated with aerial roots of Rhizophora mangle in islas del rosario, Colombia, southwestern Caribbean. Caldasia 2021, 43, 94-104. [CrossRef]

64. Baos, R.A.; Morales, S. Algae asociated to a mangrove in the Colombian Pacific. Municipio buenaventura-Valle del cauca. Fac. Cienc. Agropecu. 2007, 5, 84-89.

65. Peña, E.J. Dinámica espacial y temporal de la biomasa algal asociada a las raíces de mangle en la bahía de Buenaventura, costa pacífica de Colombia. Bol. Investig. Mar. Cost 2008, 37, 55-70. 
66. Schnetter, R.; Bula-Meyer, G. Algas Marinas del Litoral Pacífico de Colombia. Chlorophyceae, Phaeophyceae, Rhodophyceae; J. Cramer: Lehre, Germany, 1982.

67. Marín, H.; Peña, E.J. Seaweed checklist of Tumaco's bay, Colombian pacific. Hidrobiológica 2016, 26, 299-309. [CrossRef]

68. Murillo, M.; Peña, E.J. Algas marinas bentónicas de la isla gorgona, costa pacífica colombiana. Rev. Biol. Trop. 2014, 62 (Suppl. 1), 27-41. [CrossRef]

69. Rincón-Díaz, N.; Gavio, B.; Sánchez, J.V.; Chasqui, L. Crouania mageshimensis Itono, 1977 (Ceramiales, Rhodophyta) and three other species new to the eastern tropical Pacific. Check List 2020, 16, 1171-1180. [CrossRef]

70. Rincón-Díaz, N.; Sánchez, J.V.; Gavio, B.; Chasqui, L. Diversity of benthic macroalgae in the Colombian pacific: A study of a rocky reef flora. Nova Hedwig. 2021, 112, 1-15. [CrossRef]

71. Fernández, C.; Riosmena, R.; Wysor, B.; Tejada, O.L.; Cortés, J. Checklist of the Pacific marine macroalgae of central America. Bot. Mar. 2011, 54, 53-73. [CrossRef]

72. Amosu, A.O.; Robertson-Andersson, D.V.; Maneveldt, G.W.; Anderson, R.J.; Bolton, J.J. South african seaweed aquaculture: A sustainable development example for other African coastal countries. Afr. J. Agric. Res. 2013, 8, 5260-5271. [CrossRef]

73. Seaweed Aquaculture. Available online: https://www.fisheries.noaa.gov/national/aquaculture/seaweed-aquaculture (accessed on 5 May 2021).

74. Fernand, F.; Israel, A.; Skjermo, J.; Wichard, T.; Timmermans, K.R.; Golberg, A. Offshore macroalgae biomass for bioenergy production: Environmental aspects, technological achievements and challenges. Renew. Sustain. Energy Rev. 2017, 75, 35-45. [CrossRef]

75. Hafting, J.T.; Critchley, A.T.; Cornish, M.L.; Hubley, S.A.; Archibald, A.F. On-land cultivation of functional seaweed products for human usage. J. Appl. Phycol. 2012, 24, 385-392. [CrossRef]

76. Mendoza, W.; Mendola, D.; Kim, J.; Yarish, C.; Velloze, A.; Mitchell, B.G. Land-based drip-irrigated culture of Ulva compressa: The effect of culture platform design and nutrient concentration on biomass production and protein content. PLoS ONE 2018, 13, e0201675. [CrossRef]

77. Levy, I. Technology for Cultivation of Porphyra and Other Seaweeds in Land-Based Ponds; World Intellectual Property Organization: Geneva, Switzerland, 2008.

78. Algaplus. Available online: https://www.algaplus.pt/ (accessed on 20 October 2020).

79. Seakura Sea of Life. Available online: https://www.seakura.co.il/en/ (accessed on 20 October 2020).

80. AgriFutures Australia. Australian Seaweed Industry Blueprint. Available online: https://www.agrifutures.com.au/wp-content/ uploads/2020/09/20-072.pdf (accessed on 20 August 2020).

81. Algas Chile. Available online: https://www.algaschile.com (accessed on 20 October 2020).

82. Craigie, J.S.; Cornish, M.L.; Deveau, L.E. Commercialization of Irish moss aquaculture: The Canadian experience. Bot. Mar. 2019, 62, 411-432. [CrossRef]

83. Lawton, R.J.; Sutherland, J.E.; Glasson, C.R.K.; Magnusson, M.E. Selection of temperate Ulva species and cultivars for land-based cultivation and biomass applications. Algal Res. 2021, 56, 102320. [CrossRef]

84. Praeger, C.; Vucko, M.J.; de Nys, R.; Cole, A. Maximising the productivity of the attached cultivation of Ulva tepida in land-based systems. Algal Res. 2019, 40, 101507. [CrossRef]

85. Shpigel, M.; Shauli, L.; Odintsov, V.; Ashkenazi, N.; Ben-Ezra, D. Ulva lactuca biofilter from a land-based integrated multi trophic aquaculture (IMTA) system as a sole food source for the tropical sea urchin Tripneustes gratilla elatensis. Aquaculture 2018, 496, 221-231. [CrossRef]

86. Demetropoulos, C.L.; Langdon, C.J. Enhanced production of Pacific dulse (Palmaria mollis) for co-culture with abalone in a land-based system: Nitrogen, phosphorus, and trace metal nutrition. Aquaculture 2004, 235, 433-455. [CrossRef]

87. Grote, B. Recent developments in aquaculture of Palmaria palmata (Linnaeus) (Weber \& Mohr 1805): Cultivation and uses. Rev. Aquac. 2017, 11, 25-41. [CrossRef]

88. Abreu, M.H.; Pereira, R.; Yarish, C.; Buschmann, A.H.; Sousa-Pinto, I. IMTA with Gracilaria vermiculophylla: Productivity and nutrient removal performance of the seaweed in a land-based pilot scale system. Aquaculture 2011, 312, 77-87. [CrossRef]

89. Turan, G.; Neori, A. Intensive seaweed aquaculture: A potent solution against global warming. In Seaweeds and Their Role in Globally Changing Environments; Israel, A., Einav, R., Seckbach, J., Eds.; Springer: Dordrecht, The Netherlands, 2010 ; pp. $357-372$.

90. Álvarez, R.; Pardo, C.M.; Trespalacios, A.A. Evaluación y utilización potencial de las macroalgas marinas del caribe y el pacífico de Colombia: Estado actual de su conocimiento. Biosalud 2007, 6, 113-129.

91. Molina, J.N.; Álvarez, R. Resultados preliminares del cultivo experimental de Gracilaria Verrucosa (Hudson) Papenfuss (=G. caudata J. Agardh) (Rhodophyta: Gracilariaceae) en la costa caribe de Colombia. Rev. Acad. Colomb. Cienc. 2014, 38, 79-87.

92. Peña, E.J.; Álvarez, R. Experiencias en el cultivo experimental de algas rojas en el caribe y pacífico de Colombia. Rev. Luna Azul 2006, 23, 16-20.

93. Gallo, H.M.; Rincones, R.E. Factibilidad del Cultivo de Algas Marinas. Proyecto Corpoguajira/IIRBAvH/FAO. Fortalecimiento Para el Desarrollo de Empresas Rurales a Partir de Productos de la Biodiversidad en el Cabo de la Vela, Departamento de La Guajira; Consultoría Fase II: Bogotá, Colombia, 2003.

94. Montaña, J.C. Ensayos de Cultivo en Medio Natural de la Macroalga Hypnea Musciformis (Wulfen) Lamoroux en las Areas de Taganga y Puerto Luz (Santa Marta). Bachelor's Thesis, Universidad Jorge Tadeo Lozano, Cundinamarca, Colombia, 2006. 
95. Rincones, R.E.; Gallo, H. Proyecto Jimoula: El Cultivo de Algas Marinas Como Alternativa Sustentable Para las Comunidades Costeras de la Península de la Guajira; BIOTACOL Ltda.: Rioacha, Colombia, 2004.

96. Delgadillo, O.; Newmark, F. Cultivo piloto de macroalgas rojas (Rhodophyta) en Bahía Portete, La Guajira, Colombia. Bol. Investig. Mar. Cost 2008, 37, 7-26. [CrossRef]

97. Rincones, R.E.; Moreno, D.A. Aspectos técnicos y económicos para el establecimiento comercial del maricultivo de algas en Colombia: Experiencias en la península de la Guajira. Ambiente Desarro. 2011, 28, 1-52.

98. Peña, E.J.; Palacios, M.L. Introducción del alga roja Kappaphycus alvarezzi (Doty) en Colombia y experiencias de cultivo en la península de la guajira, caribe Colombiano. In Guiía de las Especies Introducidas Marinas y Costeras de Colombia; Gracia, A., Medelliín, J., Gil, D.L., Puentes, V., Eds.; INVEMAR. Ministerio de Ambiente y Desarrollo Sostenible: Santa Marta, Colombia, 2011; pp. 93-103.

99. Camacho, O.; Montaña, J. Cultivo experimental en el mar del alga roja Hypnea musciformis en el area de Santa Marta, Caribe Colombiano. Bol. Investig. Mar. Cost. 2012, 41, 29-46. [CrossRef]

100. Mosquera, Z.; Peña, E.J. Effect of salinity on growth of the green alga Caulerpa sertularioides (Bryopsidales, Chlorophyta) under laboratory conditions. Hidrobiológica 2016, 26, 277-282. [CrossRef]

101. Islam, M.; Khan, S.; Hasan, J.; Mallick, D.; Hoq, E. Seaweed Hypnea sp. culture in Cox's Bazart coast, Bangladesh. Bangladesh J. Zool. 2017, 45, 37-46. [CrossRef]

102. Pereira, S.; Kimpara, J.; Valentin, W. A simple substrate to produce the tropical epiphytic algae Hypnea pseudomusciformis. Aquac. Eng. 2020, 89, 102066. [CrossRef]

103. Ganesan, M.; Thiruppathi, S.; Jha, B. Mariculture of Hypnea musciformis (Wulfen) Lamouroux in South east coast of India. Aquaculture 2006, 256, 201-211. [CrossRef]

104. Gómez, A.; Millán, J. Cultivo experimental de Gracilaria dentata Agardh y de Gracilariopsis tenuifrons (Bird et Oliveira) (Rhodophyta: Gigartinales) en la isla de Margarita, Venezuela. Rev. Biol. Mar. Oceanogr. 1997, 32, 137-144.

105. Bermejeo, R.; Cara, C.; Macías, M.; Sánchez-García, J.; Hernández, I. Growth rates of Gracilariopsis longissima, Gracilaria bursapastoris and Chondracanthus teedei (Rhodophyta) cultured in ropes: Implication for N biomitigation in Cadiz Bay (Southern Spain). J. Appl. Phycol. 2020, 32, 1879-1891. [CrossRef]

106. Pérez-Lloréns, J.L.; Brun, F.G.; Andría, J.; Vergara, J.J. Seasonal and tidal variability of environmental carbon related physicochemical variables and inorganic $C$ acquisition in Gracilariopsis longissima and Enteromorpha intestinalis from Los Toruños salt marsh (Cádiz Bay, Spain). J. Exp. Mar. Biol. Ecol. 2004, 304, 183-201. [CrossRef]

107. Jiang, H.; Zou, D.; Lou, W.; Chen, W.; Yang, Y. Growth and photosynthesis by Gracilariopsis lemaneiformis (Gracilariales, Rhodophyta) in response to di!erent stocking densities along Nan'ao Island coastal waters. Aquaculture 2019, 501, 279-284. [CrossRef]

108. Hayashi, L.; Reis, R.P.; Alves, A.; Castelar, B.; Robledo, D.; de Vega, G.B.; Msuya, F.E.; Eswaran, K.; Yasir, S. The cultivation of Kappaphycus and Eucheuma in tropical and sub-tropical waters. In Tropical Seaweed Farming Trends, Problems and Opportunities; Hurtado, A.Q., Critchley, A.T., Neish, I.C., Eds.; Springer: Cham, Switzerland, 2017; pp. 55-90.

109. Hurtado, A.Q.; Reis, R.P.; Loureiro, R.R.; Critchley, A.T. Kappaphycus (Rhodophyta) cultivation: Problems and the impacts of acadian marine plant extract powder. In Marine Algae; Pereira, L., Neto, J.M., Eds.; Taylor \& Francis Group LLC: Oxfordshire, UK, 2014; pp. 251-299.

110. Hayashi, L.; Hurtado, A.Q.; Msuya, F.E.; Bleicher, G.; Critchley, A.T. A review of Kappaphycus farming: Prospects and constraints. In Seaweeds and Their Role in Globally Changing Enviorments; Israel, A., Einav, R., Seckbach, J., Eds.; Springer: Berlin/Heidelberg, Germany, 2010; pp. 251-283.

111. Chandrasekaran, S.; Nagendran, N.A.; Pandiaraja, D.; Krishnankutty, N.; Kamalakannan, B. Bioinvasion of Kappaphycus alvarezii on corals in the Gulf of Mannar, India. Curr. Sci. 2008, 94, 1167-1172. Available online: https://www.jstor.org/stable/24100697 (accessed on 2 December 2021).

112. Mulyani, S.; Tuwo, A.; Syamsuddin, R.; Jompa, J. Effect of seaweed Kappaphycus alvarezii aquaculture on growth and survival of coral Acropora Muricata. AACL Bioflux 2018, 11, 1792-1798.

113. Rajaram, R.; Rameshumar, S.; Ahmad, B.; Albeshr, M.F. Impacts of cultivation of red algae Kappaphycus alvarezii on planktonic and benthic faunal density in relation to environmental and hydrobiological parameters in tropical coastal ecosystem. Acta Ecol. Sin. 2021, 41, 39-49. [CrossRef]

114. Reis, R.P.; Castelar, B.; Moura, A.L.; Kirk, R. Invasive potential of Kappaphycus alvarezii off the south coast of Rio de Janeiro state, Brazil: A contribution to environmentally secure cultivation in the tropics. Bot. Mar. 2009, 52, 283-289. [CrossRef]

115. Chen, S.; Ganapin, D. Polycentric coastal and ocean management in the Caribbean sea large marine ecosystem: Harnessing community-based actions to implement regional frameworks. Environ. Dev. 2016, 17 (Suppl. 1), 264-276. [CrossRef]

116. Chen, S.; Akhtar, T.; Currea, A.M. Sustainable seaweed production, Belize. In Scaling up Community Actions for International Water Management_Experiences from the GEF Small Grants Programme; The GEF Small Grants Programme: Port Louis, Mauritius, 2016; Available online: https:/ / www.thegef.org/sites/default/files/publications/IW_PublicationCaseStudiesMay-Digital.pdf (accessed on 20 October 2020).

117. Gracilarias de Panamá. Available online: https://gracilarias.org (accessed on 10 May 2021).

118. Chung, I.K.; Sondak, C.F.A.; Beardall, J. The future of seaweed aquaculture in a rapidly changing world. Eur. J. Phycol. 2017, 52, 495-505. [CrossRef] 
119. INVEMAR. La calidad ambiental marina y costera en Colombia. In Technical Report: Informe de Estado de los Ecosistemas Marinos y Costeros; Invemar: Santa Mata, Colombia, 2004; pp. 39-74.

120. Rodríguez, L. Programa Nacional de Investigación, Evaluación, Prevención, Reducción y Control de Fuentes Terrestres y Marinas de Contaminación al Mar-Actualización del Plan de Acción 2014-2019; Comisión Colombiana Del Océano (CCO): Bogotá, Colombia, 2016; p. 70.

121. Leandro, A.; Pereira, L.; Gonçalves, A.M.M. Diverse applications of marine macroalgae. Mar. Drugs 2020, 18, 17. [CrossRef] [PubMed]

122. Sierra-Vélez, L.; Álvarez-León, R. Comparación bromatológica de las algas nativas (Gracilariopsis tenuifrons, Sargassum filipendula) y exóticas (Kappaphycus alvarezii) del caribe Colombiano. Bol. Cient. Mus. Hist. Nat. Univ. Caldas 2009, 13, 17-25.

123. Bula-Meyer, G. Marine macroalgae in the agronomy and potential use of floating Sargassum for manure production in the San Andres and Providencia Archipelago, Colombia. Rev. Intropica 2004, 1, 91-103.

124. Ospina, S.P.; López, J.B.; Márquez, M.E. Efecto antimitótico in vitro en el extracto metanólico de macroalgas marinas de la costa caribe Colombiana. Vitae 2007, 14, 84-89.

125. Ospina, M.; Castro-Vargas, H.I.; Parada-Alfonso, F. Antioxidant capacity of Colombian seaweeds: 1. extracts obtained from Gracilaria mammillaris by means of supercritical fluid extraction. J. Supercrit. Fluids 2017, 128, 314-322. [CrossRef]

126. Arteaga, M.; De Silvestri, J. Estudio de las sustancias con propiedades antimicrobianas extraordinarias de algas marinas pertenecientes al litoral atlántico colombiano. Rev. Colomb. Cienc. Químico Farm. 1985, 4, 47-52.

127. Rozo, G.; Rozo, C.; Plazas, E.; Patiño, O. Fraccionamiento bioguiado del extracto etanólico de Hypnea musciformis en búsqueda de compuestos con actividad antioxidante. Vitae 2011, 18 (Suppl. 2), S162-S163.

128. Echavarría, B.; Franco, A.; Martínez, A. Evaluación de la actividad antioxidante y determinación del contenido de compuestos fenólicos en extractos de macroalgas del caribe Colombiano. Vitae 2009, 16, 126-131.

129. Díaz, M.C.; Bula-Meyer, G.; Zea, S.; Martínez, A. Ensayos de actividad biológica y ecología química de extractos orgánicos de macroalgas del caribe Colombiano. Bol. Investig. Mar. Cost 2006, 35, 241-247.

130. Martínez, A.; Arias, L.A.; Rueda, J.L.; Diaz, M.C.; Bula-Meyer, G. Antimicrobial activity study for alcohol extracts of some macroalgae from Colombian Caribbean Sea. Vitae 2002, 9, 49-55.

131. Nuñez, E.; Arteaga, M.; Castro, M. Investigación de actividad antibacteriana de extractos de algunas algas marinas colombianas. Rev. Colomb. Cienc. Quimico Farm. 1972, 2, 123-130.

132. Sreenivasa, P.; Parekh, K. Antibacterial activity of Indian seaweed extracts. Bot. Mar. 1981, 24, 577-582. [CrossRef]

133. Valle, H.; Ospina, S.; Galeano, E.; Martínez, A.; Márquez, M.E.; López, J.B. Obtención de una fracción antimitótica del extracto etanólico de la acroalga Digenia simplex. Bol. Investig. Mar. Cost 2009, 38, 109-117.

134. Valle, H.; Ospina, S.; Galeano, E.; Martínez, A.; Marquez, M.E.; López, J.B. Componentes de la fracción antimitótica del extracto etanólico de la macroalga Digenia simplex. Vitae 2008, 15, 141-149.

135. Syad, A.N.; Rajamohamed, B.S.; Shunmugaiah, K.P.; Kasi, P.D. Neuroprotective effect of the marine macroalga Gelidiella acerosa: Identification of active compounds through bioactivity-guided fractionation. Pharm. Biol. 2016, 54, 2073-2081. [CrossRef]

136. Molina, J.N.; de la Rosa, C.R.; Olivares, L.A.; Parra, X.J.; Serrano, A. Evaluación de las condiciones de extracción de agar-agar a partir de Gracilaria verrucosa en el balneario de Santa Verónica en el departamento del atlántico. Vitae 2011, 18 (Suppl. 2), S219.

137. Monsalve-Bustamante, Y.; Rincón-Valencia, S.; Puertas-Mejía, M.; Moreno-Tirado, D.; Mejía-Giraldo, J.; Restrepo-Moná, Y. Potencial material de encapsulación a partir del alga Gracilariopsis tenuifrons del mar caribe Colombiano. Vitae 2018, 25 (Suppl. 1), 153-155.

138. Camacho, O.; Hernández-Carmona, G. Phenology and alginates of two Sargassum species from the Caribbean coast of Colombia. Cienc. Mar. 2012, 38, 381-393. [CrossRef]

139. Restrepo, N. Extracción, Purificación Y Análisis del Contenido de Fucoxantina en Algas Pardas del Caribe Colombiano. Bachelor's Thesis, Universidad de Bogotá Jorge Tadeo Lozano, Cundinamarca, Colombia, 2015.

140. Monsalve-Bustamante, Y.; Rincón-Valencia, S.; Mejía-Giraldo, J.; Moreno-Tirado, D.; Puertas-Mejía, M. Screening of the UV absorption capacity, proximal and chemical characterization of extracts, and polysaccharide fractions of the Gracilariopsis tenuifrons cultivated in Colombia. J. Appl. Pharm. Sci. 2019, 9, 103-109. [CrossRef]

141. Vargas, P.A. Efectos Fotoprotectores y Humectantes de Formulaciones Cosméticas que Contienen Extractos de Hypnea Musciformis Recolectadas en el Caribe Colombiano. Bachelor's Thesis, Universidad de Bogotá Jorge Tadeo Lozano, Cundinamarca, Colombia, 2020.

142. Ferrara, L. Seaweeds: A food for our future. J. Food Chem. Nanotechnol. 2020, 6, 56-64. [CrossRef]

143. Leandro, A.; Pacheco, D.; Cotas, J.; Marques, J.C.; Pereira, L.; Gonçalves, A.M.M. Seaweed's bioactive candidate compounds to food industry and global food security. Life 2020, 10, 140. [CrossRef] [PubMed]

144. Ullmann, J.; Grimm, D. Algae and their potential for a future bioeconomy, landless food production, and the socio-economic impact of an algae industry. Org. Agric. 2021, 11, 261-267. [CrossRef]

145. Figueroa, V.; Farfán, M.; Aguilera, J.M. Seaweeds as novel foods and source of culinary flavors. Food Rev. Int. 2021, 37, 1-26. [CrossRef]

146. Mouritsen, O.G.; Rhatigan, P.; Pérez, J.L. World cuisine of seaweeds: Science meets gastronomy. Int. J. Gastron. Food Sci. 2018, 14, 55-65. [CrossRef] 
147. Colombia Potencia Bioceánica Sostenible 2030-Documento CONPES 3990. Consejo Nacional de Politica Economica y SocialRepublica de Colombia 91. 2020. Available online: https://www.co.undp.org/content/colombia/es/home/sustainabledevelopment-goals.html (accessed on 30 May 2021).

148. Objetivos de Desarrollo Sostenible I El PNUD en Colombia. United Nations Development Programme. 2015. Available online: https://www.co.undp.org/content/colombia/es/home/sustainable-development-goals/background/ (accessed on 30 March 2021).

149. Autoridad Nacional de Acuicultura y Pesca. Plan Nacional Para el Desarrollo de la Acuicultura Sostenible en ColombiaPlaNDAS. 2014. Available online: https:/ /www.aunap.gov.co/wp-content/uploads/2016/04/Plan-Nacional-para-el-Desarrollode-la-Acuicultura-Sostenible-Colombia.pdf. (accessed on 30 May 2021).

150. Cikoš, A.M.; Jokić, S.; Šubarić, D.; Jerković, I. Overview on the application of modern methods for the extraction of bioactive compounds from marine macroalgae. Mar. Drugs 2018, 16, 348. [CrossRef]

151. Acadian Seaplants. A Sustainable Solutions for Healthier Plants, Animals and People. Available online: https://www. acadianseaplants.com/ (accessed on 20 May 2021). 